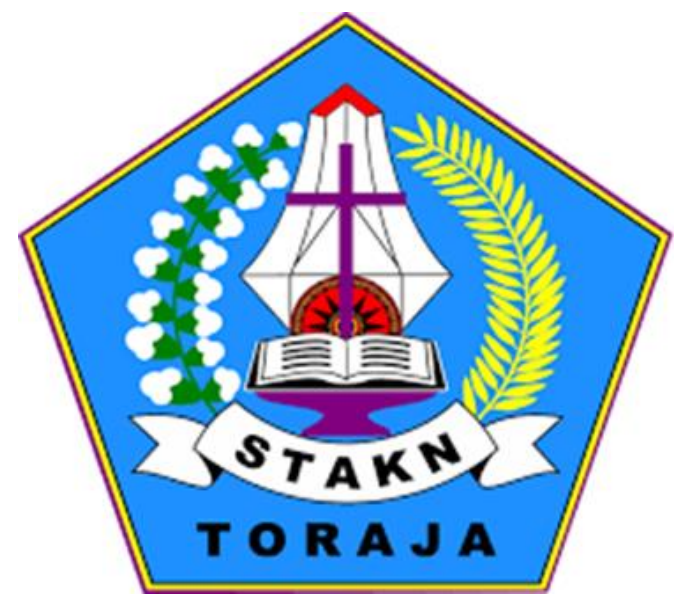

DISUSUN OLEH :

\title{
KELOMPOK 3
}

\section{KELAS F TEOLOGI}

Sriweni A.Massang

$>$ Risnatalia

$>$ Adi Sukito

$>$ Stacia Napoh Sampetoding

$>$ Monika Mangampa

$>$ Lusiana

$>$ Erika Tulak

> Gusti L.Todingbua'

INSTITUT AGAMA KRISTEN NEGERI TORAJA

(IAKN-T)

2020/2021 


\section{KATA PENGANTAR}

Puji syukur kehadirat Tuhan Yang Maha Esa atas limpahan rahmat serta kasih-Nya kepada kami, dan petunjuk-Nya sehingga memberikan kemampuan serta kemudahan bagi kami untuk menyusun makalah ini. Makalah ini dinyatakan sebagai tugas akhir untuk dari mata kuliah Teologi Perjanjian Baru 1 yang diampuh oleh dosen bapak Deflit Dujerslainm Lilo. Makalah ini ditulis dan disusun dengan satu pembahasan khusus yaitu "Evaluasi Apologis Terhadap Kritik Tinggi Alkitab dan Pengaruhnya Bagi Iman Kristen.

Menyadari bahwa keterbatasan pengetahuan serta pemahaman kami, kiranya mohon dimaklumi apabila masih terdapat banyak kekurangan serta kesalahan pada penyusunan makalah ini. Semoga makalah ini membawa manfaat bagi kita, setidaknya untuk menambah dan memberi pengetahuan yang lebih tentang pemahaman kita.

Tidak lupa kami ucapkan terima kasih kepada Bpk Deflit Dujerslainm Lilo selaku Dosen, atas bimbingan serta dukungannya, dan untuk teman-teman atas kerjasamanya. 
KATA PENGANTAR ................................................................................................................................. ii

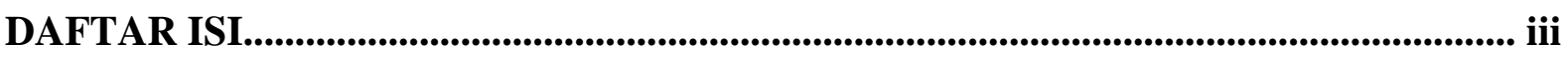

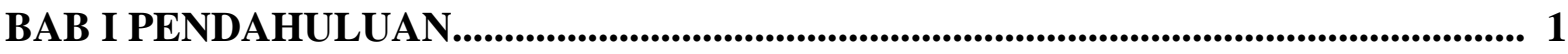

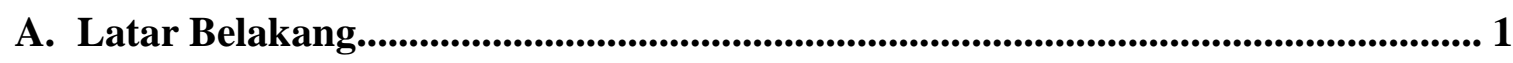

B. Rumusan Masalah.................................................................................................... 1

C. Tujuan Penulisan...................................................................................................................... . 1

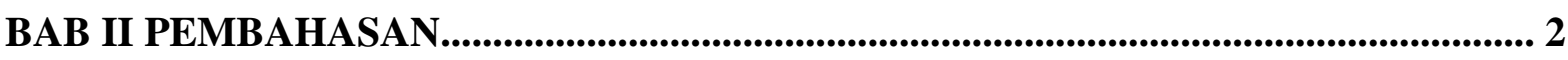

A. Pengertian Apologis.................................................................................................... 2

B. Sejarah Perkembangan Kritik Tinggi Alkitab........................................................ 2

C. Bahaya Kritik Tinggi Alkitab......................................................................... 3

D. Sikap Apologis Dalam Menghadapi Kritik Tinggi Alkitab................................ 11

E. Pengaruh Kritik Tinggi Alkitab Terhadap Iman Kristen.................................. 13

BAB III PENUTUP..................................................................................................... 14

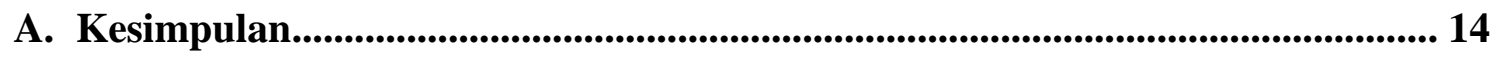

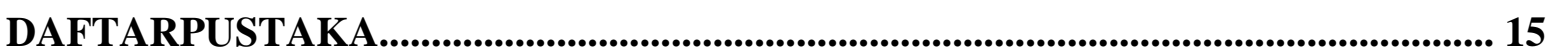




\section{BAB I}

\section{PENDAHULUAN}

\section{A. Latar Belakang}

Penafsiran Alkitab dalam masa kini terus mengalami perkembangan dengan pesat. Kemajuan ini memberikan dampak positif maupun negatif dalam dunia tafsir Alkitab. Positifnya karena dengan kemajuannya banyak nilai-nilai kebenaran yang dulu tidak dipahami mulai keluar satu persatu. Negatifnya saat kemajuan penafsiran Alkitab kehilangan batasan, dengan metode penafsiran kritik tinggi menjadikan Alkitab yang awalnya diyakini sebagai Firman yang tanpa salah, layaknya buku lain yang nilainya lebih rendah dari kitab suci.

Alkitab disejajarkan dengan buku biasa. Bahkah otoritas Alkitab sebagai Firman Allah diragukan, disangkal dan direndahkan sebatas karya sastra biasa. Ini merupakan tantangan bagai kekristenan saat ini. Diperlukan sikap yang tegas dalam menghadapi pergerakan penafsiran kritik tinggi. Orang Kristen perlu menentukan posisi dalam menangkis segala tuduhan yang merendahkan otoritas Alkitab. Segala tuduhan yang meragukan pengilhaman dan pewahyuan penulisan kitab Suci yang ada. Tulisan ini diharapkan memberikan sedikit sikap apologetika terhadap gerakan kritik tinggi.

\section{B. Rumusan Masalah}

1. Apa pengertian Apologis?

2. Bagaimana sejarah Kritik Tinggi Alkitab?

3. Apa bahaya utama Kritik Tinggi Alkitab?

4. Bagaimana sikap Apologis dalam menghadapi Kritik tinggi Alkitab?

5. Apa pengaruh Kritik tinggi alkitab terhadap Iman Kristen?

\section{Tujuan Penulisan}

1. Mengetahui apa itu Apologis

2. Mengetahui sejarah Kritik tinggi Alkitab

3. Memahami dan mengetahui bahaya utama Kritik tinggi Alkitab

4. Mengetahui sikap apologis dalam menghadapi Kritik tinggi Alkitab

5. Mengetahui pengaruh kritik tinggi alkitab terhadap Iman Kristen. 


\section{BAB II}

\section{PEMBAHASAN}

\section{A. Pengertian Apologis}

Menurut KBBI Apologis berasal dari kata apologi artinya tulisan atau pembicaraan formal yang digunakan untuk mempertahankan gagasan, kepercayaan, pembelaan ${ }^{1}$.

\section{B. Sejarah Perkembangan Kritik Tinggi Alkitab}

Pada dasarnya Kritik Alkitab (Biblical Criticism) dapat dibagi menjadi dua bagian; yaitu Kritik Tinggi (Higher Criticism) dan Kritik Rendah (Lower Criticism). ${ }^{2}$ Higher Criticism (Kritik Tinggi) sendiri merupakan studi dari yang terdiri dari penerapan pendapat yang berkaitan dengan teks atau naskah berdasarkan apa yang bisa dilihat dari sejarah, bentuk naskah, pokok bahasan dan argumen dari kitab- kitab lain; ciri dan kaitannya dengan teks; hubungan antar perikop, situasi-situasi yang diketahu penulis dan hal-hal yang berkaitan dengan pribadi penulis yang ikut andil. Istilah "kritik tinggi" bukan berarti bahwa kritikannya lebih tinggi atau lebih baik, tetapi lebih cenderung untuk membedakannya dengan kritik rendah. ${ }^{3}$

Pada awalnya baik kritik rendah, maupun kritik tinggi tidak ada penyimpangan dalam melakukan penafsiran alkitab. Keduanya dianggap sah digunakan dalam mengiteprtasikan Alkitab. Kritik rendah lebih di kenal dengan kritik teks atau kritik naskah. Kritik ini merupakan usaha untuk mendapatkan bunyi asli dengan membandingkan naskah-naskah salinan yang ada. Kritik tinggi terdiri dari kritik tentang sumber atau kritik sastra, kritik tentang bentuk dan kritik tentang redaksi.

Berjalannya waktu pengaruh rasionalisme dan evolusionisme telah meresapi liberalisme dengan kritik tinggi. Kritik tinggi, sebagaimana yang dilakukan dalam lingkungan liberal sekarang ini lebih dikenal dengan kritik historis. ${ }^{4}$ Kritik tinggi mendasari pengintepretasi Alkitab dengan menolak hal supranatural, menganggap Alkitab penuh dengan kesalahan dan juga merupakan kumpulan dari banyak mitos. Apa yang dipersalahkan oleh kritik tinggi adalah integritas, keotentikan, keterAndalan dan

\footnotetext{
${ }^{1} \mathrm{KBBI}$

${ }^{2}$ Arnold Tindas. Innerancy: Ketaksalahan Alkitab (Jogjakarta: STII Jogjakarta, 1993), hlm.4

${ }^{3}$ Herlianto.Yesus Sejarah: Siapakah Aku Ini (Bandung: Yabina, 1997), hlm.105.

${ }^{4}$ William Henry. The Higher Criticism of the Pentateuch( Grand Rapids: Baker Book House, 1978), hlm. 87.
} 
bentuk-bentuk sastra berbagai tulisan dalam Alkitab. Sedemikan jauh metode ini telah dianggap identik dengan skeptisisme, rasionalistik, suatu paham yang meragukan Alkitab karena menempatkan akal manusia diatas Alkitab. Disitulah kritik tinggi mulai membawa problem dalam penafsiran Alkitab.

\section{Bahaya Kritik Tinggi Alkitab}

Apabila kita melihat pandangan-pandangan dari Higher Criticism, seakan-akan pandangan-pandangan mereka tampak sangat ilmiah dan sangat masuk akal. Akan tetapi salah satu kesalahan dari konsep rasio adalah masalah rasionalisasi. Hal yang dilakukan oleh Higher Criticism sebenarnya adalah pemalsuan kebenaran dengan merasionalisasikannya, sehingga secara-samar-samar kebenaran yang disampaikan sangat terlihat baik dan benar, tetapi justru ada banyak penipuan didalamnya. Dan patut di waspadai bahwa gerakan ini sudah menyebar luas ke dalam pandangan teologia. Sebagai contoh jika kita membaca buku Alkitab di Dunia Modern karangan James Barr, akan di temui bahwa Alkitab dianggap sudah kadaluarsa dan Alkitab tidak memiliki relevansi dengan dunia modern..$^{5}$ justru penyimpangan- penyimpangan teologi memakai pandangan ini sebagai dasar pijakan mereka.

\section{Prasangka Negatif Adalah Dasar Pendekatan yang Dilakukan Terhadap Alkitab}

Salah satu pemikiran yang lahir pada masa Renaissance adalah kelahiran kembali dari kesusastraan klasik. Humanisme modern dalam hal ini memiliki semboyan untuk kembali kepada sumber-sumber, terutama sumber-sumber Kristen. Di dalam penelitian mereka untuk pulang kembali ke sumber-sumber tersebut mereka menerapkan prinsip bahwa manusia adalah kaidah dari segala sesuatu. Prinsip tersebut juga mendasari pemikiran dari kelompok Higher Criticism dan didalam melihat Alkitab mereka mulai dengan suatu pra-anggapan negatif. Menurut mereka bahwa tidak ada sesuatu apapun di dalam Alkitab yang bisa disebut firman Allah. Pendekatan yang mereka lakukan kepada Alkitab bukan atas dasar iman tetapi atas dasar keraguraguan. Bagian-bagian dari Alkitab dibuang kalau tidak sesuai dengan rasio, dam mereka menempatkan Alkitab sebagai obyek penelitian sejarah, yang keberadaannya tidak melebihi kitab-kitab lain.

\footnotetext{
$\overline{5}$ James Barr, Alkitab di Dunia Modern (Jakarta: BPK Gunung Mulia, 2000), hlm.5.
} 
Alkitab digolongkan sebagai kesusasteraan klasik yang sukar untuk dinikmati langsung tanpa mengadakan penyelidikan terlebih dahulu. Dalam penelitian Alkitab mereka mereka me- nyingkirkan Tuhan dan iman, dan mencarai kebenaran secara radikal. Akal kritis yang berdisplin merupakan pengendali dalam penyelidikan teologi untuk menggolongkan mana termasuk yang benar atau bukan. Akal menjadi tolak ukur kebenaran peristiwa sejarah masa lampau, masa kini dan masa yang akan datang.

Kaidah ilmiah yang berlaku adalah bahwa semua peristiwa mempunyai persamaan, karena itu harus ada langkah membanding- kan dan mempertentangkan untuk mengenali sesuatu dan hal-hal di Alkitab juga dihubungkan dengan agamaagama kuno masa lalu. Keputusan ini merupakan keputusan yang memilih hikmat duniawi untuk melihat firman Allah, sebuah keputusan yang menindas kebenaran dengan kelaliman prasangka negatif. Mereka melihat Alkitab adalah pemikiran manusia biasa, karena itu ia hanya dapat diterangkan menurut metode sejarah.

\section{Penolakan terhadap Kepenulisan Kitab-Kitab dalam Alkitab Merupakan Penolakan Terhadap Roh Kudus Sebagai Inspirator Alkitab}

Penulisan kitab yang dilakukan para penulis Alkitab tidak bisa dipisahkan dari peran Roh Kudus. Roh Kudus adalah inspirator utama bagi para penulis Alkitab menuliskan tulisannya. Penolakan terhadap kepenulisan kitab-kitab yang dilakukan oleh kelmpok higher critisism dapat digolongkan penolakan terhadap Roh Kudus sebagai insprator yang mengilhami penulis Alkitab baik secara Verbal Plenary dan Absolut Innerancy.

Kelompok higher critism melihat Alkitab dengan metode historis, sebab dengan metode tersebut mereka menyimpulkan bahwa kitab-kitab dalam Alkitab adalah tidak historis. Kelompok ini berpedapat bahwa teologi dari para penulis kitab yang keabsahan-nya pasti diragukan. Oleh karena itu teks-teks yang menge-mukakan tentang keabsolutan ajaran iman Kristen bukanlah historis, sesungguhnya bukanlah kebenaran Allah, melainkan mitos-mitos dari para penulis kitab, terutama Injil-injil sinoptik. Mereka mempersoalkan mengenai peristiwa Yesus dengan waktu penulisan yang bagi mereka tidak mungkin dijembatani. Karena ada kurang lebih lima belas atau dua puluh tahun antara peristiwa Yesus dan waktu penulisan. Bagi mereka, adalah mustahil untuk murid-murid mengingat apa yang mereka lihat dan dengar langsung dari Yesus. Jadi antara peristiwa Yesus dan waktu penulisan ada diskontinuitas. Para penulis Injil menulis hanya berlAndaskan berita-berita yang mereka kumpulkan 
berdasarkan iman mereka. Dari kesimpulan tersebut jelas bahwa kaum Pluralis tidak percaya bahwa Alkitab adalah wahyu Allah yang diinspirasikan/ diilhamkan secara verbal plenary.

\section{a. Inspirasi Verbal Plenary}

Arti kata "Inspirasi" berasal dari bahasa Yunani "theopneutos" yang secara literal berarti "nafas Allah". Hal tersebut tidak mengacu kepada, "inspirasi manusia” tetapi “inspirasi Allah". Allah menggunakan kepenulisan manusia untuk setiap Firmannya. Orang yang menuliskannya adalah orang yang dipilih oleh Allah dan dibimbing sepenuhnya oleh Roh Kudus untuk menuliskan firmanNya ke dalam tulisan tanpa ada kesalahan sedikitpun (2 Pet. 1 -21). Dalam Kis. 1-16 dan Ibrani 10:15-17 mengindikasikan bahwa Roh Allah menguasai dan mendorong orangorang untuk menulis keenam puluh enam kitab dalam Alkitab. Alkitab diilhami secara penuh dan secara verbal Alkitab mengandung nafas Allah (2 Tim. 3:16). Terdapat beberapa pemahaman kata diilhamkan dari para tokoh

1) Menurut Parditong diilhamkan artinya, "Si penulis Alkitab itu digerakan dan dipimpin oleh Allah sehingga ia dapat menuliskan kebenaran-kebenaran yang mungkin si penulis itu sudah mengetahuinya lebih dahulu tetapi juga mungkin juga ia belum mengetahuinya".

2) Menurut Wellelm kata diilhamkan artinya, "Roh Kudus telah memimpin dan menggerakan hati para penulis Alkitab sehingga apa yang ditulis mereka itu merupakan pernyataan kehendak Allah dan merupakan firman Allah”).

3) Menurut Hannah kata diilhamkan berarti, "Roh Kudus bekerja di dalam akal budi orang-orang yang menulis Alkitab itu sehingga pikiran mereka dibukakan dan mereka dapat menuliskan kebenaran-kebenaran Alkitab dengan jelas"

4) Strong $^{6}$ sendiri berpendapat, "Bila dikatakan Alkitab diilhamkan oleh Allah itu berarti Tuhan Allah menggerakkan serta memimpin pikiran orang-orang yang menulis Alkitab itu, dengan demikian Alkitab itu adalah suatu undang-undang yang tidak mungkin salah dan wajib dipercayai serta ditaati."

${ }^{6}$ A.H. Strong. 1993, Systematic Theologi (Valley Forge: Judson Press). 
5) Charles Ryrie menulis bahwa definisi dari inspirasi ${ }^{7}$ sedemikian rupa sehingga para penulis Alkitab itu menyusun dan mencatat tanpa kekeliruan pesannya kepada manusia dalam bentuk kata-kata dalam penulisannya. Yang dapat berarti bahwa adanya peluang warni-warni antara hubungan Allah dan penulisnya dan bahan yang beragam, penulisannya senantiasa meliputi penjagaan agar para penulisnya menulis dengan hati-hati, penulis bukan penulis yang pasif tetapi aktif dalam mengarang, dan tanpa keliru."

6) Dr. Strouse ${ }^{8}$ dalam eksegesis 2 Tim. $3: 16$ mengatakan, "bahwa segala tulisan yang diilhamkan oleh Allah meliputi Alkitab secara keseluruhan (Roma 9:1), dan karena bentuk kata kerjanya pasif.... maka menghasilkan kata grapheyaitu recepientaksinya, maka kitab suci itu diilhami dan penulisnya" Dapat diindikasikan bahwa yang diinspirasikan dari Allah adalah Alkitab itu sendiri dan penulisnya.

7) B.B Warfield mengulas 2 Ptr 1:21 menekankan bagian ini dengan baik. "Didalam pernyataan yang tepat dan penting dalam satu ayat ini ada yang perlu diperhatikan. Yang pertama ialah penyangkalan yang tegas bahwa nubuat - diatas hipotesa ini kita membicarakan Alkitab - berasal dari inisiatif manusia; "Tiada nubuat yang dihasilkan oleh kehendak manusia. Maka terdapat juga pernyataan yang tegas bahwa sumbernya adalah Allah. Dan sebuah anak kalimat yang jelas disisipkan dan sedemikian rupa sehingga yang ditekankan menjadi jelas yaitu bahwa manusia yang berbicara disini bukan dari mereka sendiri tetapi dari Allah: seperti didorong - dengan kata yang sama "diangkat" keatas, dan itulah yang dipakai disini seperti yang dikehendaki Roh Kudus. Demikianlah mereka berbicara di bawah pengaruh yang menentukan dari Roh Kudus, hal-hal yang mereka katakan bukanlah dari mereka sendiri tetapi dari Allah.”

8) Henry C Thiesen mengenai doktrin Alkitab tentang pengilhaman memberikan beberapa hal yang harus diperhatikan yaitu: ${ }^{9}$

a. Pengilhaman tidak dapat dijelaskan sepenuhnya. Pengilhaman merupakan adalah, "Allah mengawasi Karya Roh Kudus, namun kita tidak dapat mengetahui dengan tepat bagaimana kuasa Roh Kudus bekerja.

\footnotetext{
${ }^{7}$ Charles C. Ryrie. Teologi Dasar (Yogyakarta: Yayasan Andi, 1999), hlm. 94.

${ }^{8}$ Thomas Strouse, Doktrin Yang Benar (Jakarta: Garphe, 1996), hal. 67-68
} 
b. Pengilhaman, dalam arti terbatas ini, terbatas pada penulis-penulis Alkitab saja.

c. Kitab-kitab lainnya tidak diilhamkan seperti itu.

d. Pengilhaman pada hakikatnya merupakan tuntunan. Maksud-nya, Roh Kudus mengawasi pemilihan bahan yang dipakai serta kata-kata yang akan digunakan dalam menulis suatu kitab.

e. Roh Kudus melindungi para penulis dari berbuat kesalahan serta tidak mencatumkan apa yang tidak harus dicantumkan. Pengilhaman meliputi juga kata-kata yang dipakai, bukan sekedar pikiran dan konsepnya saja. Pengilhaman ini berlaku hanya pada kitab aslinya saja.

\section{b. Verbal dan Plenary Inspiration.}

Verbal dan Plenary maksudnya ialah: pengilhaman meliputi kata-kata yang dipakai (verbal). Matius 5:18 meng- indikasikan hal tersebut dari perkataan Tuhan Yesus yang menyatakan bahwa satu titik pun dari hukum Taurat tidak akan ditiadakan. Dan pengilhaman itu meliputi keseluruhan Alkitab/menyeluruh, artinya di dalam Alkitab itu tidak ada yang tidak diilhamkan (Plenary).

Dalam 1Kor. 2:13, Paulus menyatakan bahwa Allah datang kepada kita melalui kata-kata, dan Petrus juga mengatakan bahwa "berkata" dalam semua suratnya (2Pet.3:16). Tentu maksudnya ialah menunjuk kepada surat-surat kiriman Paulus. Ayat - ayat ini juga mengajarkan bahwa kata-kata yang dipakai dalam Alkitab adalah diilhami. Dr Thiessen melihat bahwa dari teori Verbal Plenary ini adalah sifat Allah serta tuntutan Alkitab sendiri. Dr. Thiessen dalam hal yang berhubungan dengan masalah ini mengutip pernyataan Shedd yang menulis: "Adalah tidak mungkin bahwa Tuhan akan menyatakan suatu kenyataan atau pengajaran bagi mereka, kemudian sama sekali tidak berusaha supaya kenyataan atau pengajaran tersebut disampaikan dengan benar

\footnotetext{
${ }^{9}$ Henry C. Thiessen. 1980, Lectures in Systematic Theologi (Grand rapid: Michigan, William B. Eerdmans Publishing Company), hlm. 66.
} 
Jauh lebih dapat diterima bila menganggap seseorang nabi atau rasul yang telah menerima kebenaran luhur secara langsung dari Tuhan serta tidak mungkin ditemukan dengan kecerdasan manusia tidak akan dibiarkan sendirian tanpa pengawasan dan tuntutan ketika ia menuliskannya, daripada menganggap bahwa penyampaian amanat dari Allah akan diselubungi dengan khayalan yang berlebihan."10

Sementara itu Carl Henry sehubungan dengan doktrin - inspirasi Verbal Plenary menulis; "Alkitab menegaskan bahwa inspirasi diberikan tidak hanya kepada orang-orang yang dipilih saja tetapi juga kepada tulisan-tulisannya". ${ }^{11}$ Dari pernyataan- pernyataan di atas kita dapat melihat bahwa Alkitab adalah firman Allah yang diinspirasikan. Dimana Allah menggunakan manusia untuk mencatatkan firmanNya di bawah pimpinan dan bimbingan Roh Kudus. Pengilhaman itu dilakukan terhadap tulisannya dan bukan penulisannya. Meski demikian Allah juga tetap memakai karakter dan gaya setiap penulisnya. Pengilhaman itu meliputi seluruh Alkitab bahkan tiap titik dan kata - katanya seluruhnya dikendalikan oleh Allah karena hal tersebut merupakan nafas dari Allah. Kita juga dapat berkata bahwa Alkitab adalah suara dari Allah yang duduk di atas takhtanya, setiap kata, titik dan huruf diucapkan oleh Allah yang Mahatinggi, sehingga kita atau siapapun tidak boleh menambah atau mengurangi Alkitab, sebab ia adalah Tuhan yang dalam tulisan. Oleh sebab itu Alkitab membawa serta kewibawaan illahi Allah. Yang mengikat setiap pikiran, kehendak dan hati nurani manusia. Ia juga memiliki sifat tidak mungkin bersalah, hal ini mengacu kepada naskah aslinya/ autographa dan apographa yang berisi teks autographa. Ia mengilhami orang- orang tertentu ketika menulis Alkitab dan mencerahkan pikiran orang-orang yang membaca apa yang telah diilhamkan dalam pimpinan Roh Kudus. Sangat ironis bila kritikus Alkitab menganggap bahwa Alkitab adalah sarat dengan mitos dan karangan manusia biasa. Tidak ada dasar yang kokoh dan bukti- bukti sejarah apapun bahwa Alkitab ditulis berdasarkan hasil ingatan dan pernyataan iman semata dari manusia tanpa unsur supranatural di dalamnya.

\footnotetext{
${ }^{10}$ Henry C. Thiessen, 1992. Teologi Sistematika (Malang: Gandum Mas), hlm. 100. ${ }^{11}$ Lightner dari Dewey M. Beegle, The Inspiration of the Scripture, hlm. 81
} 


\section{c. Alkitab yang Inerrancy dan Infallibility}

Masalah Alkitab yang Inerrancy dan Infallibility adalah sesuatu yang tidak disukai oleh kritikus Alkitab. Sebab doktrin ini merupakan doktrin yang sangat menegaskan tentang kebenaran Alkitab. Apakah 'Inerrancy' itu? Dan apakah yang dimaksud dengan 'Infallibility' itu? 'Inerrancy' adalah pandangan bahwa ketika seluruh fakta ditunjukkan, mereka akan menunjukkan bahwa Alkitab di dalam teks aslinya (authographa) adalah benar dan tidak ditemukan kesalahan baik dalam hubungannya dengan doktrin, etika, sosial, kronologi, sejarah, ilmu pengetahuan dan sebagainya. Sedangkan 'Infallibility' berarti tidak ada kemungkinan gagal atau tidak tepat.

\section{Pandangan Higher Criticism Merupakan Dasar Bagi Teolog Yesus Sejarah dan} Pluralisme

Pandangan Higher Criticism ini merupakan dasar dari penyimpangan teologia yang meliputi teologi Liberal, Neo- Ortodoks, Teologi Proses, teologi Pembebasan dan beberapa teologi yang lain. Namun untuk masa sekarang teologi yang berbahaya bagi Kristologi adalan Yesus sejarah yang juga sangat mempelopori konsep Pluralisme.

Penganut Yesus Sejarah adalah mereka yang mempersoal- kan Yesus sejarah melalui relasi yang kritis mengenai relasi antara peristiwa Yesus dan waktu penulisan dan pandangan ini juga menjadi dasar utama kelompok pluralisme. Mereka menyimpulkan bahwa apa yang ditulis oleh para penulis Injil tentang Yesus, sebenarnya bukanlah Yesus sesungguhnya atau bukan Yesus yang benar-benar ada secara historis, melainkan Yesus yang menurut pikiran murid atau para penulis Injil. Karena itu Yesus yang dikenal dari Alkitab oleh orang Kristen sekarang, bukan Yesus sebenarnya me-lainkan Yesus mitos para penulis Injil. Penelitian tentang Yesus sejarah ini muncul pertama kali dari metode penelitian kritik bentuk dan kritik redaksi oleh kaum Liberal.

Erickson berpendapat bahwa orientasi penelitian ini ialah: Untuk menemukan seperti apakah Yesus sesungguh-nya dan apakah Ia memang datang, dikenal sebagai "Search For Historical Jesus" yang mendasari penyelidikan ini adalah pengharapan bahwa Yesus yang sesungguhnya akan terbukti berbeda dengan Kristus yang nampak dalam Alkitab, dan yang berada dalam beberapa pengertian sebagai hasil dari proses 
teologi Paulus dan penulis yang lain. Mereka mengumpulkan ucapan-ucapan yesus yang ditulis dalam Injil sinoptik dan injil Yohanes. Ucapan-ucapan itu kemudian disusun untuk merekonstruksikan sejarah kehidupan Yesus. Selain itu, Jesus Seminar mencoba untuk memperjelas pemi-sahan antara 'Yesus Sejarah' dan 'Yesus Iman'. ${ }^{2}$

Sebenarnya ada empat tokoh yang memulai penelitian tentang Yesus sejarah ini, yaitu David Strauss dengan bukunya "A New Life Of Jesus" dan Ernast Renan. Keduanya meman-dang Yesus sebagai manusia biasa yang baik, sebagai seorang guru yang memiliki kebenaran-kebenaran rohani karena itu mereka menolak keillahian Yesus. Kemudian. Adolf Von Harnack dengan bukunya yang terkenal "What is Christianity?" berpendapat bahwa; Injil- injil tidak mem-berikan kepada kita arti mengenai susunan biografi Yesus, karena mereka menceritakan kepada kita sedikit mengenai awal kehidupan Yesus Dan Albert Schweitzer dengan bukunya "Quest of the Historical Jesus" membangun asumsinya dengan menyatakan bahwa Injil-injil adalah tidak dapat dipercaya dan bahwa Yesus sejarah adalah seorang yang biasa, sebagai dongeng yang telah mengalami perkembangan.

Jadi penyelidik Yesus sejarah melihat Yesus hanya sebagai manusia biasa saja yang rohani dan bermoral serta memiliki kebenaran-kebenaran rohani. Akhirnya penyelidikan Yesus sejarah ini terus menerus berkembang yang pada dasarnya isu sebenarnya adalah tidak mempercayai kitab Injil-injil Kanonik sebagai sumber pemahaman tentang Yesus. Sebalik-nya buku-buku Yesus Sejarah memberikan gambaran Yesus dan catatan mengenai asal muasal kekristenan tanpa mengacu pada sumber kitab-kitab: misi Yesus hanya digambarkan sebagai pejuang sosial dan menggambarkan aspek utama yaitu rohani membuang semua unsur-unsur supranatural, menghilangkan inti utama dari kekristenan dan membuang pandangan Kristen tradisional. Memandang Yesus sebagai manusia biasa yang baik dan bermoral tinggi dan yang patut diteladani oleh orang Kristen. Inilah fakta yang sudah dan sedang merusak kekristenan dewasa ini.

Roy Eckardt yang dapat juga disebut sebagai seorang teolog Pluralis menyatakan bahwa: "Kristologi harus dida-sarkan pada Yesus Sejarah. Atau lebih baik lagi, pengkajian ini mendekati persoalan Kristologi dari suatu pandangan sejarah umum diterima sekarang.

\footnotetext{
${ }^{12}$ Herlianto.1997. Yesus Sejarah,(Yabina),hal.69-70
} 
"Yesus sejarah yang dimaksudkan adalah Yesus "Sang Kristus" berarti membuat suatu pernyataan iman yang tidak dapat dibuktikan (atau tidak dapat disangkal oleh sejarah). Ioanes Rahmat juga seorang yang dapat disebut teolog Pluralis Indonesia, ia juga merupakan penganut Yesus Sejarah. Ia percaya bahwa kematian tentang Yesus dalam Injil-injil adalah ciptaan penulis, dan ia pun membedakan ucapan asli Tuhan Yesus dan yang produk dari para penulis (Yesus Seminar: Yesus tidak pernah menuntut diriNya disebut dan diakui sebagai Mesias. Hal ini merupakan kesalahan para murid Yesus dan orang Kristen masa kini) ${ }^{13}$ Macus J. Borg menggali ulang Yesus dan menegaskan bahwa memahami Yesus sejarah berarti memahami Yesus yang sesungguhnya Disamping Yesus Sejarah, beberapa kaum Pluralis juga percaya kepada Yesus kepercayaan, dengan kata lain bahwa Yesus yang dikisahkan dalam Injil-injil bukanlah Yesus yang ada secara historis, melainkan Yesus yang ditangkap oleh iman para penulis Injil.151 ${ }^{14}$ Oleh sebab itu mereka menganggap Injil penuh dengan dongeng dan mitos. Dengan demikian mereka mencela orang Kristen yang terlalu menekankan finalitas Yesus Kristus dan kemutlakan-Nya. Mereka ingin menafsir ulang InjiL dan membersihkan semua yang mereka anggap sebagai mitos.

\section{Sikap Apologis Dalam Menghadapi Kritik Tinggi Alkitab}

Dalam menghadapi gerakan Higher Criticism maka ada beberapa hal yang harus dipegang oleh orang Kristen terutama berhubungan dengan masalah pengajaran. Hal utama yang harus dilakukan oleh umat Kristen dalam memenggal gerakan kritik ini adalah dengan menggali dan mengetahui kebenaran kekristenan itu dengan sebaikbaiknya. Pengetahuan yang benar terhadap kebenaran adalah modal dasar yang kuat untuk menghadapi kesesatan. Pengetahuan utama tentang kebenaran itu sendiri meliputi beberapa tema utama kekristenan.

\section{Pentingnya Mengetahui Otoritas Alkitab Yang Mutlak}

Alkitab merupakan dasar dari seluruh doktrin kekris- tenan, juga merupakan standar hidup orang Kristen. Bila otoritas Alkitab diragukan maka

\footnotetext{
${ }^{13}$ Iones Rahmat. Serba - serbi doktrin : Yesuslah Satu - satunya jalan, hal. 8-9. ${ }^{14}$ Marcus J. Borg. 1998, Kali Pertama Jumpa Yesus Kembali (Jakarta: BPK Gunung Mulia).
} 
mustahil seseorang bisa percaya kepada Allah Sang Pencipta dan pemelihara alam semesta. Menganggap Alkitab sebagai mitos merupakan sebuah keko-nyolan, sebab kebenarannya ditulis langsung oleh orang per-tama dan diakui orang-orang yang sekontemporer dengannya sehubungan dengan peristiwa-peristiwa di dalamnya. R.C. Sproul menyatakan bahwa Allah mewahyukan diriNya kepada kita di dalam sebuah buku. ${ }^{15}$

Buku itu ditulis dalam kata-kata. Kata-kata itu menge- mukakan konsepkonsep yang harus dimengerti akal. Tentu saja masih ada misteri. Misteri ini bukanlah sesuatu yang bertentangan dengan rasio, akan tetapi jauh melampaui rasio itu sendiri yang harus dilihat dengan iman. Kemudian Alkitab itu sendiri merupakan inspirasi Allah secara Verbal Plenary yang absolut Innerancy dan Infalibility, yang kebenarannya tidak dapat diragu- kan sedikitpun bahkan terhadap hal-hal sekuler lainnya yang terjadi di dalam dunia ini.

\section{Keselamatan Adalah Hal yang Paling Utama}

Keselamatan adalah pusat dari segala-galanya. Seseorang akan hidup sia-sia tanpa dirinya sendiri sudah diselamatkan. Keselamatan akan dimiliki dengan baik, apabila mengetahui dan menerima kebenaran itu dengan baik. Tanpa mengetahui arti keselamatan yang benar seseorang tidak akan mungkin diselamatkan. Keselamatan hanya ada didalam Kristus (Yoh.14: 6, Kis.4:12). Dan Alkitab merupakan buku yang dituliskan supaya manusia mengetahui kebenaran ini, "tetapi semua yang telah tercantum di sini telah dicatat, supaya kamu percaya, bahwa Yesuslah Mesias, Anak allah, dan supaya kamu oleh imanmu memperoleh hidup dalam namaNya” (Yohanes 20:31).

Kristuslah pusat keselamatan, dan pengorbanan Kristus untuk menanggung dosa manusia merupakan inti Injil. Ini merupakan dasar yang utama ketika mempelajari Alkitab, dan penyimpangan tidak akan mungkin terjadi sebab iluminasi Roh Kudus akan mendominasi seluruh pikiran kita untuk melihat Alkitab. Untuk mengerti hikmat Allah, kita harus memiliki pikiran Allah yaitu Roh Kudus, untuk memiliki Roh Kudus, kita harus bertobat dan menerima Kristus sebagai juru selamat pribadi, dengan demikian Dia akan memeteraikan kita dengan Roh Kudus (Efesus 1:13:14).

${ }^{15}$ R.C. Sproul. 2002, Kebenaran-Kebenaran Dasar Iman Kristen (Malang: Departemen Literatur SAAT), hlm. xxi. 


\section{Perlunya Belajar Teologi yang Tepat}

Alkitab adalah firman Allah dan kebenaran teologi harus bersumber dan berpusat dari sana sehingga manusia dapat mengerti dan memahami firman Allah. Akan tetapi ketika Alkitab bukan lagi dianggap sebagai firman Allah, maka teologi yang dihasilkan akan menjadi sebuah kesesatan, dan berapa banyakkah orang menyadari bahwa hal ini.

Pandangan Higher Criticism, telah menyesatkan penikiran berjuta-juta manusia tanpa mereka sadari. Mereka telah ter- perangkap dalam filsafat yang ateis dan menyimpangkan iman yang benar. Alkitab tidak pernah salah dan menyesatkan, akan tetapi ia banyak disimpangkan oleh konsep ilmu pengetahuan dan filsafat humanisme sekuler, yang akhirnya menjadi racun yang mematikan bagi gereja. Oleh sebab itu, untuk bisa memahami pikiran yang sesat terutama dari kelompok ini dan membuka topeng kesesatan itu, diperlukan suatu pendidikan teologi yang benar yang takut akan Tuhan. Dengan pemahaman teologi yang baik kita bisa melihat Alkitab sebagai wahyu yang diinspirasikan oleh Allah, dan pengetahuan yang mendasar tentang seluruh firman Allah, dapat dipakai oleh Allah untuk menelanjangi teologi yang miring dan membongkar semua kedok mereka.

\section{E. Pengaruh Kritik Tinggi Alkitab Terhadap Iman Kristen}

Pendidikan teologi Higher Criticism menghasilkan pendeta yang tidak percaya bahwa seseorang harus lahir baru dan bertobat, maka jemaatnya pun tidak akan tahu hal itu. Dan mereka juga tidak lagi meyakini bahwa Alkitab itu benar, akibatnya mereka menghasilkan kotbah-kotbah yang semu, hal hal yang bersifat praktikal tanpa mengikat, akibatnya jemaat tidak lagi mendapat pengajaran yang jelas, melainkan berbagai tafsiran Alkitab yang menyimpang. Dengan demikian tidak ada lagi pembaharuan hidup dan pertumbuhan iman juga tidak mungkin terjadi. Demikianlah terbentuk jemaat- jemaat, yang tidak lagi mendengar pembacaan Alkitab secara pribadi, persekutuan rohani dan kebenaran yang sejati. 


\section{BAB III}

\section{PENUTUP}

\section{A. Kesimpulan}

Dalam menghadapi gerakan Higher Criticism maka ada beberapa hal yang harus dipegang oleh orang Kristen terutama berhubungan dengan masalah pengajaran serta pengetahuan yang benar terhadap kebenaran yang mana merupakan modal dasar yang kuat untuk menghadapi kesesatan. Pengetahuan utama tentang kebenaran itu sendiri meliputi beberapa tema utama kekristenan.ialah :
a) Pentingnya mengetahui otoritas Alkitab yang mutlak,
b) Keselamatan adalah HAL yang paling utama,
c) Perlunya belajar Teologi yang tepat 


\section{DAFTAR PUSTAKA}

Barr, James. 2000, “Alkitab di Dunia Modern”, Jakarta: BPK Gunung Mulia.

Borg, Marcus J.1998, Kali Pertama Jumpa Yesus Kembali, Jakarta: BPK Gunung Mulia.

Herlianto.1997, Yesus Sejarah: Siapakah Aku Ini, Bandung: Yabina. Ryrie, Charles C. 1999, Teologi Dasar. Yogyakarta: Andi.

Tindas, Arnold. 1993, Innerancy: Ketaksalahan Alkitab, Jogjakarta: STII. Strong, A.H. 1993, Systematic Theologi, Valley Forge: Judson Press.

Strouse, Thomas, 1996, Doktrin Yang Benar, Jakarta: Garphe.

Thiessen, Henry C. 1980, Lectures in Systematic Theologi, Grand rapid: Michigan, William B. Eerdmans Publishing Company.

Thiessen, Henry C. 1992. Teologi Sistematika. Malang: Gandum Mas.

Sproul, R.C. 2002, Kebenaran-Kebenaran Dasar Iman Kristen, Malang: Departemen Literatur SAAT.

William Henry. 1978, The Higher Criticism of the Pentateuch, Grand Rapids: Baker Book House.

Youngblood, Ronal. 1978, "Introduction" The Higher Criticism of the Pentateuch, Grand Rapids, Michigan:Baker Book House. 